\title{
Užpakalinės grižtamosios encefalopatijos sindromas: klinikinio atvejo pristatymas ir literatūros apžvalga
}

\author{
G. V. Urbonaitė* \\ E. Audronytë** \\ J. Valaikiene $\dot{e}^{* *}$ \\ *Vilniaus universiteto \\ Medicinos fakultetas \\ **Vilniaus universiteto \\ Medicinos fakultetas, \\ Neurologijos centras
}

\begin{abstract}
Santrauka. Užpakalinės grịžtamosios encefalopatijos sindromas (angl. Posterior reversible encephalopathy syndrome, PRES) - retas sutrikimas, kurio diagnostika remiasi būdingais klinikiniais ir radiologiniais pakitimais. Dažniausiai šis sindromas pasireiškia ūmiu neurologiniu sindromu su galvos skausmais, sutrikusia sąmone, traukulių priepuoliais ir (ar) regos sutrikimais, kuriuos lydi arterinio kraujospūdžio svyravimai, bei būdingu neuroradiologiniu vaizdu - abipuse požievio vazogenine edema, labiausiai išreikšta pakaušinėse srityse. Nors tikslus patofiziologinis PRES mechanizmas lieka kontraversiškas, manoma, kad sindromo išsivystymą lemia endotelio disfunkcija. PRES būtina ịtarti, kai ūmi neurologinė simptomatika pasireiškia pacientams su inkstų nepakankamumu, arterine hipertenzija ir kraujospūdžio svyravimais, eklampsija, sepsiu, autoimuninėmis ligomis, vartojantiems imunosupresinius ar citotoksinius vaistus. Pagrindinis šio sindromo gydymas - jị sukẻlusių priežasčiu šalinimas (arterinio kraujospūdžio korekcija, imunosupresinių vaistų dozès sumažinimas ar nutraukimas). Prognozė dažniausiai yra gera - tiek klinikiniai simptomai, tiek radiologiniai pakitimai regresuoja per keletą dienų ar savaičių. Labai retai PRES gali komplikuotis ūmia intracerebrine hemoragija, ryškia smegenų edema ir fataline išeitimi ar sunkiu invalidumu.

Straipsnyje pristatomas retas klinikinis atvejis, kai PRES buvo nustatytas atsitiktinai, atliekant planinị magnetinio rezonanso tyrimą dèl diagnozuotos meningiomos. Ligonis, kuri kelerius metus vargino galvos skausmai, sirgo lengva pirminès arterinès hipertenzijos forma su kraujospūdžio svyravimais. PRES būdingi MRT pakitimai išliko po 1,3 bei 6 mènesių ir visiškai regresavo praejus metams.
\end{abstract}

Raktažodžiai: arterinė hipertenzija, užpakalinės grižtamosios encefalopatijos sindromas, PRES, hipertenzinė encefalopatija, meningioma, galvos skausmai.

\section{IVADAS}

Užpakalinès grịžtamosios encefalopatijos sindromas (angl. Posterior reversible encephalopathy syndrome, PRES) pirmą kartą aprašytas Hinchey ir kt. 1996 m., atlikus išsamią ligonių su inkstų nepakankamumu, arterine hipertenzija, eklampsija ar imunosupresine būkle klinikinių simptomų bei kompiuterinès tomografijos (KT) ir (ar) magnetinio rezonanso tomografijos (MRT) vaizdų analizę [1]. Tai klinikinis neuroradiologinis sutrikimas, kuriam būdinga tipiška grižtama galvos smegenų medžiagos ede-

\author{
Adresas: \\ Greta Veronika Urbonaite \\ Vilniaus universiteto Medicinos fakultetas \\ M. K. Čiurlionio g. 21, LT-03101 Vilnius \\ El.paštas greta.v.urbonaite@gmail.com
}

ma, dažniausiai išsivystanti abiejose pakaušinėse skiltyse, bei naujai atsiradę neurologiniai simptomai - nelokalizuoti galvos skausmai, traukuliai, sąmonès sutrikimas, regèjimo sutrikimai [1-5]. Kai kuriuose literatūros šaltiniuose vartojami ir šie terminai: grịžtamosios užpakalinès leukoencefalopatijos sindromas, užpakalinès leukoencefalopatijos sindromas, grižtamosios užpakalinès smegenų edemos sindromas, hiperperfuzinè encefalopatija, grižtamoji okcipitoparietalinè encefalopatija $[1,2,6]$. Nè vienas iš šių pavadinimų nèra visiškai tikslus, nes pakitimai ne visada būna grižtami (reversiniai) ir dažnai apima ne vien tik baltają medžiagą ir parietookcipitalines sritis. Nustačius, kad sindromui būdingi ne tik baltosios medžiagos pakitimai (leukoencefalopatija), bet ir galvos smegenų žievès pakitimai, vietoj anksčiau vartoto grįžtamosios užpakalinės leukoencefalopatijos pavadinimo sutartinai imtas vartoti PRES terminas.

\footnotetext{
(C) Neurologijos seminarai, 2020. Open Access. This article is distributed under the terms of the Creative Commons Attribution 4.0 International License CC-BY 4.0 (http://creativecommons.org/licenses/by/4.0/), which permits unrestricted use, distribution, and reproduction in any medium, provided you give appropriate credit to the original author(s) and the source, provide a link to the Creative Commons license, and indicate if changes were made.
} 

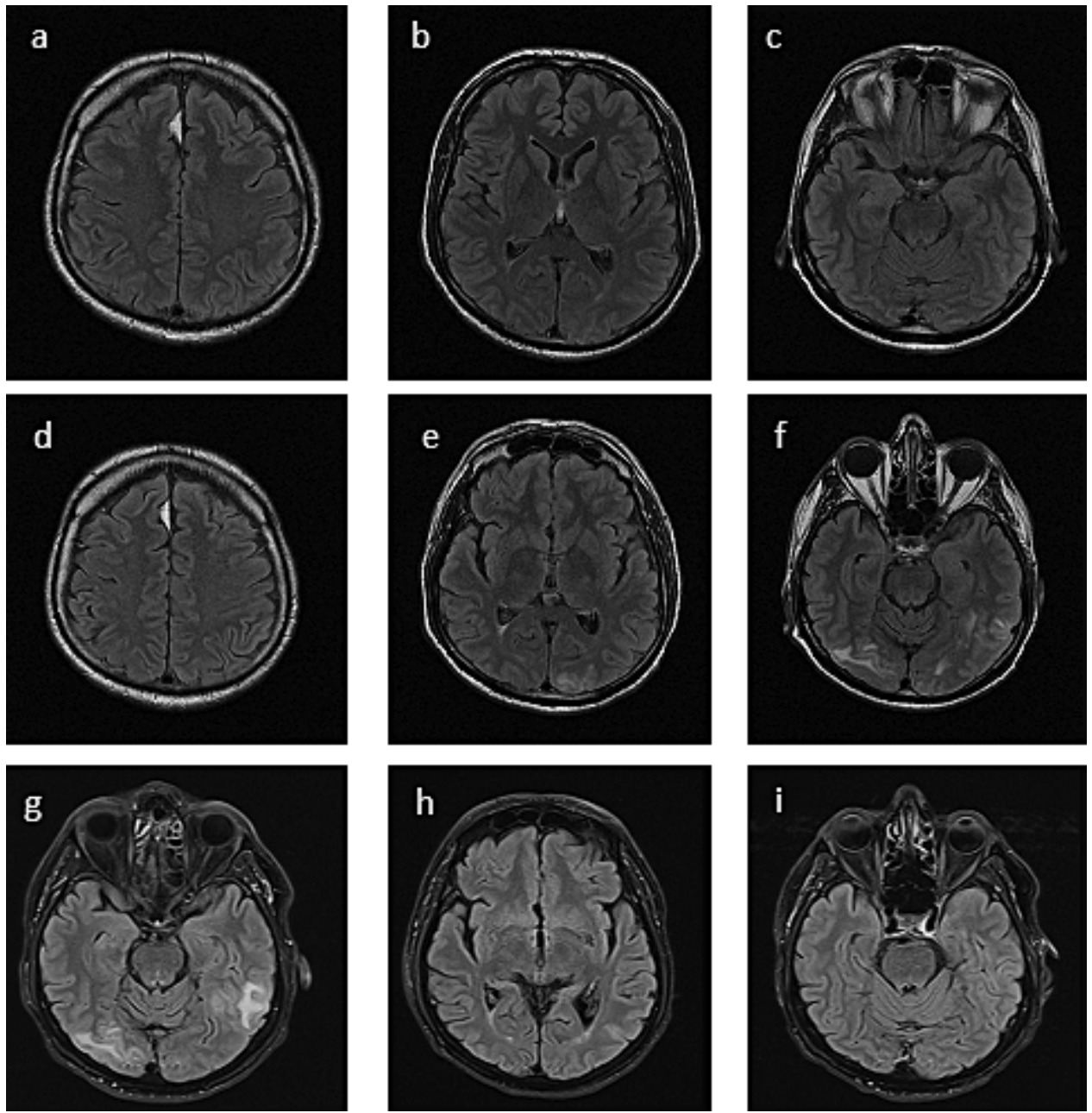

1 pav. Galvos magnetinio rezonanso tomografijos (MRT) vaizdų dinamika: atsiradęs ir regresavęs užpakalinės grižtamosios encefalopatijos sindromas

a - galvos MRT (2016 m.): kalcifikuota meningioma falx cerebri dešineje frontalinėje srityje; b, c - normalus smegenu vaizdas; $\mathrm{d}$ (2018 m. vasario mèn.) - kalcinatas dinamikoje nesikeičia; e, $\mathrm{f}$ - dinamikoje abipus okcipitalinėse skiltyse atsirado hiperintensinio signalo zonos T2, FLAIR sekose; g (2018 m. birželio mèn.) - dešinėje okcipitalinėje srityje pakitimai išliko, kairẻje - sumažejo, bet atsirado nauji analogiški pakitimai kairèje temporalinèje srityje tse-dark fluid sekose; h, i (2019 m. birželio mèn.) - hiperintensinio signalo zonos visiškai regresavo.

Straipsnyje pristatome retą klinikinị atvejị, kai PRES buvo diagnozuotas vyresnio amžiaus vyrui su pirmos stadijos arterine hipertenzija ir cefalginiu sindromu, atliekant planini galvos MRT tyrimą meningiomai stebèti.

\section{ATVEJO APRAŠYMAS}

59 metu pacientas kreipèsi dèl nuolatinių difuzinių galvos skausmų (3-4 balų su dažnais pablogèjimais iki stipraus intensyvumo), regejjimo sutrikimo (liejosi vaizdas akyse). Galvos skausmai prasidejjo prieš ketverius metus staiga, pabudus iš miego. Kreipèsi i vaistininkę, nustatytas arterinio kraujo spaudimo (AKS) padidejjimas iki $180 \mathrm{mmHg}$, skirti vaistai nuo AKS, pasak ligonio, nepadejo. Galvos skausmų etiologijai tikslinti prieš dvejus metus atlikta galvos MRT, diagnozuota apie $13 \mathrm{~mm}$ kalcifikuota didžiojo smegenų pjautuvo falx cerebri meningioma (1 pav. a), kurią nutarta stebèti dèl galimo augimo. MRT duomenimis, galvos smegenų požievio / žievès pakitimų nenustatyta (1 pav. b, c). Kardiologui diagnozavus pirminę arterinę hipertenziją (PAH), skirtas pastovus gydymas metoprololiu ir perindopriliu. Kadangi, paciento nuomone, antihipertenziniai vaistai galvos skausmų nesumažino, po kelių mènesiu jis šių vaistų vartojimą savavališkai nutraukè. Galvos skausmai suintensyvejo, ėmè varginti nemiga, palaipsniui èmè silpti atmintis, epizodiškai liejosi vaizdas akyse. Pakartojus galvos MRT, meningiomos pokyčiu dinamikos nestebèta (1 pav. d), bet abiejose pakaušinèse skiltyse T2 režimu nustatyti hiperintensinio signalo židiniai su mikrohemoragijomis be difuzijos restrikcijos (1 pav. e, f). İtarus PRES, pacientas hospitalizuotas į Nervų ligų skyrių.

Skyriuje pacientas naujų skundų neišsakè, neurologinio ištyrimo metu patologinių pakitimų nebuvo nustatyta. AKS - 140/90 mmHg. Laboratoriniai kraujo tyrimai (bendras, biocheminis, koaguliagrama ir D-dimerai) atitiko normą. Siekiant ekskliuduoti galvos veninių sinusų trombozę ir grižtamosios cerebrinès vazokonstrikcijos sindro- 
mą (angl. Reversible cerebral vasoconstriction syndrome, RCVS), atlikta galvos MRT su kontrastine medžiaga ir angiografijos režimu. Kraujagysliụ patologija ekskliuduota, dešinėje pakaušinėje skiltyje pakitimai išliko, kairejje pakaušinejje skiltyje subkortikaliai nežymiai sumažèję, analogiški nauji būdingi PRES pakitimai nustatyti kaireje temporookcipitalineje srityje (1 pav. g). Gydymui skirta $50 \mathrm{mg}$ metoprololio ir $5 \mathrm{mg}$ ramiprilio per dieną. Esant lètinio skausmo sindromui, skirta $10 \mathrm{mg}$ amitriptilino. Po savaitės, koregavus AKS (120/80 mmHg), galvos skausmu intensyvumas sumažèjo, regos sutrikimais nesiskundè. Išrašant pacientą iš ligoninès, rekomenduota tęsti antihipertenzini gydymą, vartoti amitriptiliną.

Po trijų mėnesių ligoniui pakartojus galvos MRT, hiperintensiniai židiniai kaireje temporalinėje zonoje buvo mažesnès apimties ir sumažejusio signalo intensyvumo, o abipusiai okcipitaliai - išlikę. Galvos skausmai buvo mažesnio intensyvumo, retesni (kartą per savaitę). Atlikus MRT po vienerių metų, PRES būdingi pakitimai buvo visiškai regresavę (1 pav. h, i). Klinikinè ligonio būklè buvo pagerẻjusi, bet išliko protarpiniai galvos skausmai (dažniau rytais), susiję su AKS nestabilumu - AKS pakilimu ar žemo AKS epizodais.

\section{LITERATŪROS APŽVALGA IR ATVEJO APTARIMAS}

\section{Epidemiologija}

Tikslus PRES paplitimas populiacijoje nėra žinomas. Nors sindromas gali pasireikšti įvairiame amžiuje (nuo 2 iki 90 metų), dauguma PRES atvejų diagnozuojama nuo 20 iki 65 metų [7]. Kai kurių autorių duomenimis, dažniau serga moterys, netgi ekskliudavus eklampsijos atvejus [2, 6-8].

\section{Etiopatogenezè}

Nors iki šiol nustatyta daug veiksnių, kurie gali sąlygoti PRES, tačiau kai kuriais atvejais priežastis lieka neaiški [9]. Šis sindromas dažniausiai pasireiškia pacientams su inkstų pažeidimu (iki $55 \%$ atvejų), arterine hipertenzija ir AKS svyravimais, eklampsija, autoimuninemis ligomis (pvz., sisteminè raudonoji vilkligè), sepsiu, vartojantiems citotoksinius, chemoterapinius ar imunosupresinius vaistus (ypač ciklosporiną) $[1,2]$ (1 lentelè). Pastaruoju metu pasirodè pranešimai apie PRES atvejus, pasireiškusius ūmaus respiracinio sindromo koronaviruso-2 (SARS-CoV-2) sukeltos koronaviruso-19 ligos (COVID-19) pacientams [10].

Nors tikslus patofiziologinis mechanizmas iki šiol nèra išaiškintas, manoma, kad PRES išsivystymą lemia endotelio disfunkcija. Vyrauja dvi pagrindinès hipotezès. Pirmoji teigia, kad, įvykus hipertenzinei krizei, sutrinka smegenu autoreguliacija, išsivysto smegenų hiperperfuzija ir hematoencefalinio barjero disfunkcija. Antroji yra susijusi su citotoksiniu poveikiu, sukeliančiu endotelio disfunkciją, he-
1 lentelè. Etiologiniai užpakalinès grị̌tamosios encefalopatijos sindromo veiksniai (pagal Toledano ir kt., 2017) [2]

\begin{tabular}{||l||}
\hline Eklampsija \\
\hline Arterinė hipertenzija ir (ar) arterinio kraujospūdžio \\
svyravimai \\
Hipertenzinė encefalopatija \\
Disautonomija (pvz., Guillan-Barré sindromas, nugaros \\
smegenų trauma) \\
Jatrogeninė hipertenzija (pvz., vazospazmo gydymas po \\
subarachnoidinės hemoragijos) \\
\hline Autoimuninės ligos \\
Jungiamojo audinio uždegiminės ligos \\
Skleroderma \\
Sjogreno liga \\
Sisteminė raudonoji vilkligė \\
Vaskulitai \\
Uždegiminės žarnyno ligos \\
Hashimoto tiroiditas \\
Pirminis sklerozuojantis cholangitas \\
Trombocitopeninė purpura \\
Hemolizinis ureminis sindromas \\
\hline Infekcija / sepsis / šokas \\
\hline Imunosupresiniai / imunomuduliaciniai / citotoksiniai / \\
chemoterapiniai vaistai \\
Angiogenezės inhibitoriai \\
Bevazicumabas \\
Tirozinkinazės inhibitoriai \\
Kalcineurino inhibitoriai \\
Ciklosporinas A \\
Takrolimas \\
Cisplatina ir kiti platinos chemoterapiniai vaistai \\
Interferonas alfa \\
Metotreksatas \\
Rituksimabas \\
Vinkristinas \\
\hline Kiti \\
Ūmus arba lėtinis inkstų nepakankamumas \\
Kraujo transfuzijos \\
Amfetamino / kokaino vartojimas \\
Hiperkalcemija / hipomagnezemija / hiponatremija \\
\hline
\end{tabular}

matoencefalinio barjero pažeidimą ir smegenų hipoperfuziją. Abiem atvejais, sutrikus smegenų perfuzijai, išsivysto vazogeninè smegenų edema [6].

Kai vidutinis arterinis spaudimas svyruoja tarp 50 ir $150 \mathrm{mmHg}$, vyksta normali smegenų kraujotakos autoreguliacija [2,5]. Kai jis tampa mažesnis negu $50 \mathrm{mmHg}$, gali atsirasti hipoperfuzija ir išemija, kai didesnis negu $150 \mathrm{mmHg}$ - hiperperfuzija, tai gali sukelti arteriolių išsiplètimą, plazmos ir makromolekulių ekstravazaciją ir vazogeninę edemą [2]. Kraujagyslių tonusas kinta, reaguodamas ị anglies dvideginio kiekị kraujyje ir spaudimą [3, 5]. Endotelis taip pat prisideda prie kraujagyslių tonuso reguliavimo, išskirdamas vazodilatatorius (azoto oksidas, 
2 lentelè. Užpakalinės grị̌̌tamosios encefalopatijos sindromo klasifikacija, vertinant MRT pakitimų išplitimą (pagal Brady ir kt., 2018) [7]

\begin{tabular}{||l|l|l|l|l||}
\hline Laipsnis & Vazogeninės edemos apimtis & $\begin{array}{l}\text { Smegenų struktūrų } \\
\text { itraukimas }\end{array}$ & $\begin{array}{l}\text { Parenchimos } \\
\text { hemoragijos }\end{array}$ & Masės efektas \\
\hline I. Lengvas & $\begin{array}{l}\text { Žievės ar požievio baltosios } \\
\text { medžiagos edema }\end{array}$ & $\begin{array}{l}\text { Nė vienos / viena iš šių } \\
\text { sričių: smegenėlės, smegenų } \\
\text { kamienas, pamato branduoliai }\end{array}$ & Nėra & Nėra \\
\hline II. Vidutinis & $\begin{array}{l}\text { Susiliejanti edema, neapimanti } \\
\text { periventrikulinės baltosios } \\
\text { medžiagos }\end{array}$ & $\begin{array}{l}\text { Dvi iš šių sričių: smegenėlės, } \\
\text { smegenų kamienas, pamato } \\
\text { branduoliai }\end{array}$ & Yra arba nėra & $\begin{array}{l}\text { Nedidelis, be vidurinės linijos } \\
\text { poslinkio ar strigimo }\end{array}$ \\
\hline III. Sunkus & $\begin{array}{l}\text { Susiliejanti edema, apimanti } \\
\text { periventrikulinę baltają } \\
\text { medžiagą }\end{array}$ & $\begin{array}{l}\text { Visos trys sritys: smegenėlės, } \\
\text { smegenų kamienas, pamato } \\
\text { branduoliai }\end{array}$ & Yra arba nėra & $\begin{array}{l}\text { Yra su vidurinės linijos } \\
\text { poslinkiu ar strigimu }\end{array}$ \\
\hline
\end{tabular}

prostaciklinas) ir vazokonstriktorius (tromboksanas A2, endotelinas-1) [3,5]. Taigi, PRES išsivysto, kai yra pažeidžiami smegenų kraujotakos reguliaciniai procesai. Yra keletas teorijų, aiškinančių PRES patogenezę, kurias galima suskirstyti i hiperperfuzijos ir hipoperfuzijos / endotelio pažeidimo $[11,12]$.

Pagrindinè ir daugiausia pripažinimo susilaukè ,vazogeniné“ teorija. Remiantis šia teorija, staigiai besivystanti hipertenzija sukelia sutrikimus smegenų kraujotakos autoreguliacijoje ir, ivvykus hiperperfuzijai bei plazmos ir makromolekulių ekstravazacijai, išsivysto vazogeninè edema $[3,13]$. Šią teoriją pagrindžia tai, kad maždaug $50 \%$ PRES pacientų turi aukštą AKS ir, taikant antihipertenzini gydymą, radiologiniai pakitimai, klinikiniai simptomai ir požymiai regresuoja $[5,14]$. PRES dažniausiai nustatomas užpakalinėse smegenų zonose, kurios turi menkesnę simpatinę inervaciją ir yra mažiau atsparios hipertenzijai $[5,15]$.

Kadangi „vazogenine““ teorija nepaaiškina atvejų, kaip PRES išsivysto, esant normotenzijai, buvo pasiūlytos kitos teorijos, teigiančios, kad pirmiausia įvyksta endotelio pažeidimas, po to vystosi vazokonstrikcija, hipoperfuzija ir išemija, kas lemia vazogeninès edemos išsivystymą [3, 12, 13]. Remiantis šiomis teorijomis, aukštas AKS atsiranda kaip endotelio pažeidimo rezultatas $[12,13]$.

"Citotoksinë“ teorija teigia, kad pirminis pažeidimas kyla dèl endogeninių stimuliantų (pvz., chemokinai) arba egzogeninių toksinų (pvz., chemoterapiniai arba imunosupresiniai vaistai) $[3,13]$. COVID-19 atveju masyvus citokinu atsipalaidavimas („citokinų audra“) gali pažeisti hematoencefalinį barjerą ir sukelti PRES [10]. Remiantis „imunogenine“ teorija, yra aktyvuojami T limfocitai ir skatinamas citokinų išsiskyrimas [3, 13, 16]. Citokinai aktyvuoja endotelio ląsteles, stiprèja leukocitų adhezija ir didèja endotelio pralaidumas, vystosi smegenų edema [5, 16]. Astrocitai pradeda stipriau ekspresuoti kraujagyslinio endotelio augimo faktorių, kuris taip pat didina endotelio pralaidumą $[5,11,16]$. „Neuropeptidų“ teorija akcentuoja vazokonstriktorių, tokių kaip: endotelinas-1, prostaciklinas ir tromboksanas A2, svarbą hipoperfuzijos ir išemijos bei edemos vystymesi $[3,13]$.

Neseniai buvo iškelta dar viena teorija, kurios teigimu, arginino vazopresino receptorių aktyvacija lemia PRES išsivystymą [11]. Ši teorija grindžiama tuo, kad dauguma PRES etiologinių veiksnių skatina arginino vazopresino sekreciją arba jo receptorių ekspresiją, kas vėliau taip pat skatina vazokonstrikciją, hipoperfuziją ir vazogeninę edemą [11].

\section{KLINIKINIAI SIMPTOMAI IR POŽYMIAI}

PRES pradžia dažniausiai yra poūmè, tačiau gali manifestuoti ir traukulių priepuoliu. Dažniausi klinikiniai simptomai ir požymiai PRES atveju yra galvos skausmai, pakitusi sąmonès būklè (nuo budrumo sutrikimo iki komos), traukuliai, regėjimo sutrikimai $[1,2,5,6,14,17]$. Literatūros duomenimis, sąmonès sutrikimai (encefalopatija) pasireiškia 28-94 \%, generalizuoti traukulių priepuoliai 60-75\% (rečiau - daliniai priepuoliai, epilepsinè būklè), galvos skausmai - 50 \%, regèjimo sutrikimai - 33-39\% [3, 8, 14, 17]. Pasitaiko lengvų klinikinių PRES formų (pvz., izoliuotas galvos skausmas, sumišimas), vidutinių ir sunkių (epilepsinė būklè, koma), dažniausiai susijusių su hemoraginėmis komplikacijomis (2 lentelè). Galvos skausmai, susiję su PRES, dažniausiai būna difuziniai, su pykinimu, vėmimu, palaipsniui stiprèjantys, o ne staiga atsiradę „perkūno trenksmo“ pobūdžio skausmai, būdingi subarachnoidinei hemoragijai (SAH) arba RCVS [2, 17]. Regėjimo sutrikimai gali pasireikšti sumažèjusiu regèjimo stiprumu, diplopija, žieviniu aklumu, regos haliucinacijomis $[2,3,17]$. Hemiparezè, afazija ir kiti židininiai neurologiniai simptomai pasireiškia rečiau, maždaug 10-15\% pacientų $[3,5]$.

\section{DIAGNOSTIKA}

PRES diagnostikai dažniausiai naudojama galvos MRT, kuri yra jautresnis tyrimas nei galvos KT, kadangi pokyčių KT gali nesimatyti arba jie gali būti nespecifiniai $[6,18]$. Galvos KT gali būti naudinga, nesant galimybės atlikti MRT. Tokiu atveju galima aptikti hipodensinius židinius tipiškose srityse, diagnozuoti hemoragijų buvimą ir sunkaus PRES atvejus [6, 8].

Pagrindinis požymis, matomas MRT T2 FLAIR (Fluid-Attenuated-Inversion-Recovery) sekoje, yra simetrinė vazogeninè subkortikinė / požievio baltosios medžia- 
3 lentelè. Užpakalinès grị̌ztamosios encefalopatijos diferencinè diagnostika [5, 6, 23]

\begin{tabular}{|c|c|}
\hline Sutrikimas & Būdingi požymiai \\
\hline Smegenų insultas & Pasireiškia arterijos baseine, vienpusis. \\
\hline Hipertenzinè encefalopatija & $\begin{array}{l}\text { Dažniausiai paveikia baltają medžiagą, užpakalinėse smegenų srityse, kartu nustatomi kitu } \\
\text { organų-taikinių (inkstai, tinklainė) pažeidimai, aukštas arterinis kraujo spaudimas. }\end{array}$ \\
\hline RCVS & $\begin{array}{l}\text { Nustatomi bent du susiaurèjimai arterijoje ir šie pokyčiai randami bent dviejose smegenų } \\
\text { arterijose. }\end{array}$ \\
\hline Galvos veninių sinusų trombozė & Nustatoma galvinių sinusų trombozè. \\
\hline Infekcinis encefalitas & Smegenų skystyje - pleocitozė, nustatomas sukèlèjas, būdingas karščiavimas. \\
\hline $\begin{array}{l}\text { Autoimuninis / paraneoplastinis } \\
\text { encefalitas }\end{array}$ & $\begin{array}{l}\text { Nustatomi specifiniai antikūnai smegenų skystyje arba kraujyje, anamnezèje piktybinio } \\
\text { naviko diagnoze. }\end{array}$ \\
\hline $\begin{array}{l}\text { Smegenų navikas arba } \\
\text { metastazès }\end{array}$ & $\begin{array}{l}\text { Atipinės ląstelès smegenų skystyje, anamnezėje piktybinio naviko diagnozė ir (ar) svorio } \\
\text { kritimas. }\end{array}$ \\
\hline $\begin{array}{l}\text { Ūminis demielinizuojantis } \\
\text { encefalomielitas }\end{array}$ & $\begin{array}{l}\text { Dažniau serga vaikai, dažniausiai po vakcinacijos arba persirgtų infekcinių ligų, } \\
\text { karščiavimas - 50-75 \% atvejų. }\end{array}$ \\
\hline Toksinė leukoencefalopatija & $\begin{array}{l}\text { Anamnezejje narkotinių medžiagų vartojimas ir (ar) teigiami narkotinių medžiagų testai, } \\
\text { magnetinio rezonanso spektroskopija gali rodyti padidejjusią laktato ir sumažejusią } \\
\text { N-acetilaspartato koncentracijas. }\end{array}$ \\
\hline $\begin{array}{l}\text { Centrinès nervų sistemos } \\
\text { vaskulitas }\end{array}$ & $\begin{array}{l}\text { Dažniausiai poūmè pradžia, smegenų skystyje - pleocitozė, neurovizualiniuose tyrimuose } \\
\text { vyrauja citotoksinės edemos vaizdas. }\end{array}$ \\
\hline $\begin{array}{l}\text { Progresuojanti daugiažidininè } \\
\text { leukoencefalopatija }\end{array}$ & $\begin{array}{l}\text { Daug židinių, nustatoma John Cunningham viruso DNR, būdingas galūnių silpnumas, } \\
\text { židininiai neurologiniai simptomai. }\end{array}$ \\
\hline MELAS & $\begin{array}{l}\text { Teigiama šeiminė anamnezè, būdinga kurtumas, oftalmoplegija, miopatija, magnetinio rezonan- } \\
\text { so spektroskopija gali rodyti padidejusią laktato ir sumažejusią N-acetilaspartato koncentracijas. }\end{array}$ \\
\hline CADASIL & Simetriškai paveikta baltoji medžiaga ir bazaliniai ganglijai, išsiplètę perivaskuliniai tarpai. \\
\hline
\end{tabular}

Santrumpos: RCVS - grịžtamosios cerebrinės vazokonstrikcijos sindromas, MELAS - mitochondrinė encefalomiopatija, laktatacidozè ir insultą primenanti būklè, CADASIL - cerebrinè autosominè dominantiné arteriopatija su subkortikiniais infarktais ir leukoencefalopatija.

gos ir kortikinė / žievès edema, dažniausiai (98 \%) pasireiškianti parietookcipitalinejje srityje, momeninių skilčių užpakalinėse zonose ir pakaušinėse skiltyse [7, 19-21]. Kartu gali būti paveikiamos ir kitos zonos: kaktinė skiltis $(50-79 \%)$, smilkininès zonos $(65 \%)$ ir smegenèlès $(30-53 \%)$ [7, 20]. PRES gali pasireikšti ir atipinėse zonose: gumbure / thalamus (20-30 \%), pamato branduoliuose / bazaliniuose ganglijuose (12-34 \%), apatineje smilkininèje-pakaušinėje / temporalinèje-okcipitalinèje srityje (40\%), smegenėlèse (32\%), smegenų kamiene (13-27\%), giliojoje baltojoje medžiagoje (18\%), didžiosios smegenų jungties užpakalinėje dalyje (10 \%) [7, 20-22]. Kai kurių autorių nuomone, retai pasitaikantis izoliuotas užpakalinės duobės struktūrų pažeidimas gali būti susijęs su itin aukštu AKS [20].

Bartynski ir kt. 2007 m., atliktoje retrospektyvioje studijoje išanalizavę 136 ligonių KT $(n=22)$ ir MRT $(n=114)$ duomenis, aprašė pagrindinius PRES pasiskirstymo tipus: 1) viso pusrutulio arba holohemisferinis paribinių zonų tipas $(22,8 \%)$ - linijinè vazogeninė edema apima kaktines, momenines, pakaušines, iš dalies temporalines skiltis priekinės ir užpakalinės smegenų arterijų bei vidurinės smegenų arterijos baseinų anastomozių srityje; 2) viršutinès kaktinès vagos tipas $(27,2 \%)$ apima kaktines skiltis (linijinio pobūdžio, pagal viršutinę kaktinę vagą), su ịvairaus lygio momeninių ir pakaušinių skilčių ịtraukimu; 3) dominuojantis momeninių-pakaušinių skilčių tipas $(22,1 \%)$ apima momenines ir pakaušines skiltis, su ịvairaus lygio smilkini- nių skilčių ịtraukimu; 4) dalinės arba asimetrinès pirminių tipų išraiškos tipas $(27,9$ \%) apima tuos vazogeninès edemos atvejus, kai pirmieji trys tipai yra tik iš dalies išreikšti. Šiam tipui būdingi mažesnès apimties smegenų pakitimai, galintys būti išsidèstę ne tik linijomis, bet ir atskirais edemos ploteliais. Dalinės PRES ekspresijos atveju nèra abiejų momeninių arba pakaušinių skilčių patologinių signalo pakitimų, tačiau gali būti ịtrauktos kitos būdingos smegenų pusrutulių dalys. Asimetrinei (vienpusei) PRES ekspresijai būdinga tai, kad yra tik vienos pusès momeninès arba pakaušinès skilties edema. Rečiausiai pasitaiko mišrus dalinès ir asimetrinès PRES ekspresijos variantas [21].

Be MRT T2 FLAIR sekos, kurioje matomi hiperintensiniai signalai paveiktose smegenų dalyse, PRES diagnozei nustatyti naudojamos ir DWI (Diffusion-weighted imaging) bei ADC (Apparent diffusion coefficient) sekos, siekiant diferencijuoti PRES nuo kitų sutrikimų, pavyzdžiui, smegenų insulto [7, 20, 23] (3 lentelè). Kadangi PRES sukelia vazogeninę edemą, itrauktose zonose matomi hipo- arba izointensiniai signalai DWI sekoje ir hiperintensiniai signalai ADC sekoje $[17,18,21]$. Insulto atveju DWI sekoje matytųsi hiperintensinis signalas, o ADC - hipointensinis, kadangi šiuo atveju vyrauja citotoksinè edema, be to, pažeidimo zonos apimtų konkrečios smegenų arterijos baseiną $[17,18,21]$. Dar viena, labai panaši i PRES patologija - hipertenzinè encefalopatija (HE). HE patogenezė ir radiologiniai vaizdai yra panašūs ị PRES, tačiau HE atveju visada nustatomas aukštas AKS (dažniau- 


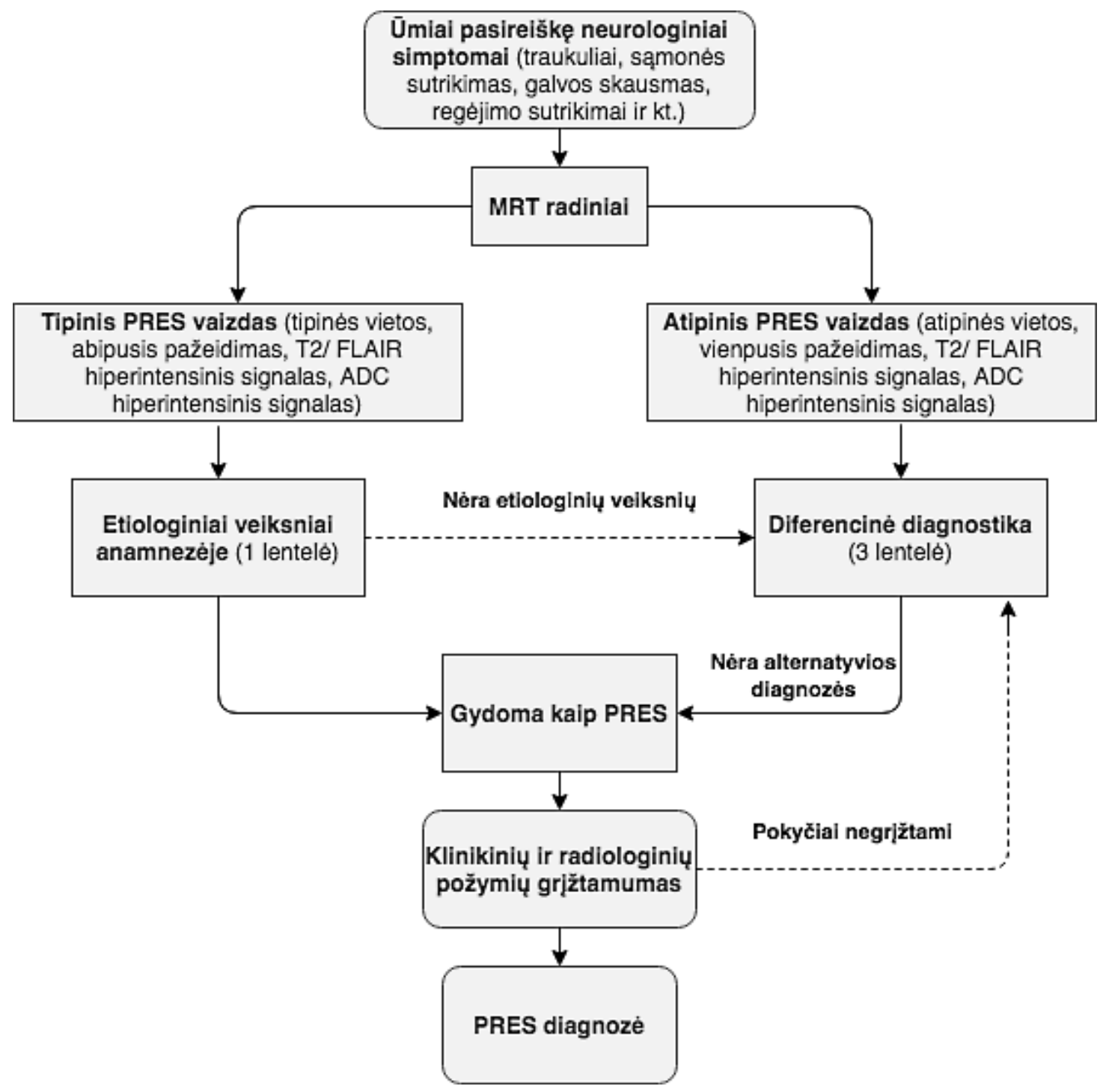

2 pav. Užpakalinės grižtamosios encefalopatijos diagnozavimo schema (pagal Tetsuka ir kt., 2019) [23]

Santrumpos: MRT - magnetinio rezonanso tyrimas; PRES - užpakalinės grįžtamosios encefalopatijos sindromas.

siai daugiau nei 220/120 mmHg; arba diastolinis - bent jau daugiau kaip $100 \mathrm{mmHg}$ ) ir organų-taikinių pažeidimas (pvz., abipusė regos nervų diskų edema, ūminis inkstų nepakankamumas, širdies nepakankamumas) [16].

Kai kuriuose klinikiniuose tyrimuose buvo naudojamas ir kontrasto (gadolinio) kaupimas. Tačiau buvo ịrodyta, kad kontrasto kaupimas nekoreliuoja nei su MRT matomų vaizdų sunkumu, nei su PRES išeitimis, tad šis tyrimas PRES diagnostikai nèra rekomenduojamas [9]. Tačiau, esant atipiniam PRES pasireiškimui, gali būti papildomai naudojama magnetinio rezonanso spektroskopija, kurios metu matomi sumažèję N-acetilaspartato (NAA) ir kreatinino bei NAA ir cholino santykiai; fotonų emisijos tomografija (PET) - matomas sumažejęs fluordeoksigliukozès ir metionino kaupimas [24].

Kartu su PRES 15-64 \% atvejų gali būti nustatomos intrakranijinès hemoragijos - nuo mikrohemoragijų, kurias lengviausia aptikti, naudojant SWI (Susceptibilityweighted imaging) seką, iki SAH ir intracerebrinių kraujosruvų su vidurinès linijos dislokacija, sąlygojančių blogą ligos išeiti [7, 20]. Naujausios literatūros duomenimis, aprašyti pirmieji hemoraginio PRES atvejai, susiję su COVID-19 infekcija [10]. Be to, net iki $85 \%$ atvejų kartu su PRES nustatomi ir RCVS būdingi arterijų susiaurèjimai, todèl manoma, kad abu šie sutrikimai persidengia ir turi panašią patogenezę bei priklauso tam pačiam sutrikimų spektrui [7, 20].

Nors tikslių gairių PRES diagnozuoti nėra, dažniausiai remiamasi ūmių neurologinių simptomų išsivystymu, etiologinių veiksnių buvimu anamnezèje ir tipiniais MRT radiniais. Remdamiesi esamomis žiniomis apie PRES ir šio sindromo požymius, Tetsuka ir kt. 2019 m. pasiūlè PRES diagnozavimo schemą (2 pav.).

\section{GYDYMO PRINCIPAI}

Diagnozavus PRES, svarbiausia yra skubiai pašalinti sindromą sukèlusią priežastị ir nedelsiant pradèti simptominị gydymą, esant reikalui - intensyviosios terapijos skyriuje. 
Jeigu PRES išsivystymą sąlygojo chemoterapiniai ar imunosupresiniai vaistai, jų dozès turètų būti sumažintos arba vartojimas visiškai nutrauktas $[8,17]$. Jei diagnozuota preeklampsija ar eklampsija kartu su PRES, indikuotinas magnio sulfatas ir neatidèliotinas gimdymas [17, 25]. Traukuliams gydyti siūloma vartoti intraveninius antiepileptinius vaistus, pavyzdžiui, diazepamą ar levetiracetamą $[17,19]$. Esant epilepsinei būklei, siūlomi ir propofolis ar midazolamas $[17,19]$. Hipertenziją siūloma mažinti palaipsniui, ne daugiau nei 20-25\% per pirmas šešias valandas, kad būtų išvengta smegenų miokardo ir inkstų išemijos [15, 17]. Norint išvengti AKS svyravimų, siūloma naudoti intraveninius antihipertenzinius vaistus: pirmos eilès - labetaloli, nikardipiną, antros eilès - natrio nitroprusidą, hidralaziną [17, 25]. Reikètų vengti nitroglicerino, kadangi yra aprašyta atvejų, kai šis vaistas pablogino PRES eigą [3, 14].

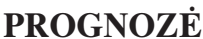

Nors apie $90 \%$ pacientų visiškai pasveiksta ir jiems nelieka jokio neurologinio deficito, mirštamumas nuo PRES siekia 8-19\% [7, 13, 26]. Irodyta, kad preeklampsijos / eklampsijos atveju PRES išeitys būna geresnès, negu kitu etiologinių veiksnių sąlygotais atvejais $[13,26]$. Pagrindiniai rizikos veiksniai, susiję su padidejjusiu mirštamumu, yra hemoragijų (pvz., SAH), pakitusios sąmonės būsenos, išemijos zonų ir koaguliopatijų buvimas [3, 13, 26]. Didelè CRB koncentracija kraujyje taip pat sietina su bloga prognoze, tačiau didžiausią įtaką tam daro PRES sukėlę infekciniai procesai (pvz., sepsis) [3, 13, 17]. Taip pat nustatyta, kad cukrinis diabetas ir didžiosios smegenų jungties ịtraukimas ị procesą yra susiję su blogesnėmis išeitimis [13, 17].

\section{ATVEJO APTARIMAS}

İdomu tai, kad aprašytajam pacientui PRES nepasireiškẻ ūmiais neurologiniais simptomais. Taip pat ligoniui neprireikè intraveninių antihipertenzinių vaistų, kadangi jam nustatyta hipertenzija buvo I lygio (remiantis Europos kardiologijos ir Europos hipertenzijos asociacijų (angl. European Society of Cardiology, ESC; European Society of Hypertension, ESH) 2018 metų rekomendacijomis) [27]. Tačiau negalima paneigti, kad pacientas turèjo ir aukštesni AKS, prieš jam atvykstant ị ligoninę. Be to, iš anamnezès žinoma, kad pacientas nesilaikẻ gydytojų nurodymų reguliariai vartoti antihipertenzinius vaistus, ir tikètina, kad būtent AKS svyravimai sukèlè PRES išsivystymą. MRT buvo matomas PRES būdingas vaizdas ir buvo ekskliuduoti kiti galimi sutrikimai (RCVS, smegenų veninių sinusų trombozè). HE taip pat buvo galima atmesti, kadangi nebuvo stebimas organų-taikinių pažeidimas. Po metų kontrolinẻje galvos MRT jokių PRES būdingų židinių galvos smegenyse nebuvo stebèta, falx cerebri kalcifikatas išliko ne- pakitęs. Todèl, remiantis Tetsuka ir kt. pasiūlyta diagnozavimo schema, net ir nesant ūmių neurologinių simptomų, galima daryti išvadą, kad PRES buvo diagnozuotas teisingai.

\section{IŠVADOS}

1. Klinikinị radiologinị PRES sindromą reikia ịtarti, kai ūmi neurologinè simptomatika pasireiškia ligoniams, sergantiems inkstų nepakankamumu, arterine hipertenzija ir kraujospūdžio svyravimais, eklampsija, sepsiu, autoimuninėmis ligomis, vartojant imunosupresinius ar citotoksinius vaistus, ir SARS-CoV-2 infekcijos atveju.

2. Nors PRES būdingas ūmus neurologinès simptomatikos pasireiškimas, esant lengvai klinikinei formai, jis gali būti nustatomas netikètai, kartojant planinę galvos MRT dẻl meningiomos ar kitų priežasčių.

3. Netgi nedidelio laipsnio arterinè hipertenzija su kraujospūdžio svyravimais gali sąlygoti būdingus PRES pakitimus MRT, esant lètinio galvos skausmo su pablogejjimais klinikai.

4. Laiku diagnozavus PRES ir skubiai taikant tinkamą gydymą, dažniausiai prognozė būna gera - klinikiniai ir neuroradiologiniai pakitimai visiškai regresuoja.

\section{Literatūra}

1. Hinchey J, Chaves C, Appignani B, Breen J, Pao L, Wang A, et al. A reversible posterior leukoencephalopathy syndrome. N Engl J Med 1996; 334(8): 494-500. https://doi.org/ 10.1056/NEJM199602223340803

2. Toledano M, Fugate JE. Posterior reversible encephalopathy in the intensive care unit. Handb Clin Neurol 2017; 141: 467-83. https://doi.org/10.1016/B978-0-444-635990.00026-0

3. Liman TG, Siebert E, Endres M. Posterior reversible encephalopathy syndrome. Curr Opin Neurol 2019; 32(1): 25-35. https://doi.org/10.1097/WCO.0000000000000640

4. Zelaya JE, A1-Khoury L. Posterior Reversible Encephalopathy Syndrome (PRES). Treasure Island, Florida: StatPearls Publishing, 2020. Available from: https://www.ncbi.nlm.nih.gov/books/NBK554492/

5. Fugate JE, Rabinstein AA. Posterior reversible encephalopathy syndrome: clinical and radiological manifestations, pathophysiology, and outstanding questions. Lancet Neurol 2015; 14: 914-25. https://doi.org/10.1016/S14744422(15)00111-8

6. Legriel S, Pico F, Azoulay E. Understanding posterior reversible encephalopathy syndrome. In: Vincent JL, ed. Annual Update in Intensive Care and Emergency Medicine. Berlin, Heidelberg: Springer, 2011; 631-53. https://doi.org/ 10.1007/978-3-642-18081-1_56

7. Brady E, Parikh NS, Navi BB, Gupta A, Schweitzer AD. The imaging spectrum of posterior reversible encephalopathy syndrome: a pictorial review. Clin Imaging 2018; 47: 80-9. https://doi.org/10.1016/j.clinimag.2017.08.008

8. Fischer M, Schmutzhard E. Posterior reversible encephalopathy syndrome. J Neurol 2017; 264: 1608-16. https://doi.org/10.1007/s00415-016-8377-8 
9. Karia SJ, Rykken JB, McKinney ZJ, Zhang L, McKinney AM. Utility and significance of gadoliniumbased contrast enhancement in posterior reversible encephalopathy syndrome. Am J Neuroradiol 2016; 37(3): 415-22. https://doi.org/10.3174/ajnr.A4563

10. Franceschi AM, Ahmed O, Giliberto L, Castillo M. Hemorrhagic posterior reversible encephalopathy syndrome as a manifestation of COVID-19 infection. AJNR Am J Neuroradiol 2020; 41(7): 1173-6. https://doi.org/10.3174/ ajnr.A6595

11. Largeau B, Le Tilly O, Sautenet B, Salmon Gandonnière C, Barin-Le Guellec C, Ehrmann S. Arginine vasopressin and posterior reversible encephalopathy syndrome pathophysiology: the missing link? Front Neurol 2019; 56: 6792-806. https://doi.org/10.1007/s12035-019-1553-y

12. Racchiusa S, Mormina E, Ax A, Musumeci O, Longo M, Granata F. Posterior reversible encephalopathy syndrome (PRES) and infection: a systematic review of the literature. Neurol Sci 2019; 40: 915-22. https://doi.org/10.1007/ s10072-018-3651-4

13. Gao B, Lyu C, Lerner A, McKinney AM. Controversy of posterior reversible encephalopathy syndrome: what have we learnt in the last 20 years? J Neurol Neurosurg Psychiatry 2018; 89: 14-20. https://doi.org/10.1136/jnnp-2017-316225

14. Granata G, Greco A, Iannella G, Granata M, Manno A, Savastano E, et al. Posterior reversible encephalopathy syndrome-insight into pathogenesis, clinical variants and treatment approaches. Autoimmun Rev 2015; 14: 830-6. https://doi.org/10.1016/j.autrev.2015.05.006

15. Le EM, Loghin ME. Posterior reversible encephalopathy syndrome: a neurologic phenomenon in cancer patients. Curr Oncol Rep 2014; 16(5): 1-9. https://doi.org/10.1007/ s11912-014-0383-3

16. Chen Z, Shen GQ, Lerner A, Gao B. Immune system activation in the pathogenesis of posterior reversible encephalopathy syndrome. Brain Res Bull 2017; 131: 93-9. https://doi.org/10.1016/j.brainresbull.2017.03.012

17. Hinduja A. Posterior reversible encephalopathy syndrome: clinical features and outcome. Front Neurol 2020; 11: 71. https://doi.org/10.3389/fneur.2020.00071

18. Shankar J, Banfield J. Posterior reversible encephalopathy syndrome: a review. Can Assoc Radiol J 2017; 68(2): 147-53. https://doi.org/10.1016/j.carj.2016.08.005

19. Miller JB, Suchdev K, Jayaprakash N, Hrabec D, Sood A, Sharma $\mathrm{S}$, et al. New developments in hypertensive encephalopathy. Curr Hypertens Rep 2018; 20: 1-7. https://doi.org/10.1007/s11906-018-0813-y

20. Ollivier M, Bertrand A, Clarençon F, Gerber S, Deltour S, Domont $F$, et al. Neuroimaging features in posterior reversible encephalopathy syndrome: a pictorial review. J Neurol Sci 2017; 373: 188-200. https://doi.org/10.1016/j.jns. 2016.12.007

21. Bartynski WS, Boardman JF. Distinct imaging patterns and lesion distribution in posterior reversible encephalopathy syndrome. Am J Neuroradiol 2007; 28(7): 1320-7. https://doi.org/10.3174/ajnr.A0549

22. Saad AF, Chaudhari R, Wintermark M. Imaging of atypical and complicated posterior reversible encephalopathy syndrome. Front Neurol 2019; 10: 964. https://doi.org/10.3389/ fneur.2019.00964

23. Tetsuka S, Ogawa T. Posterior reversible encephalopathy syndrome: a review with emphasis on neuroimaging characteristics. J Neurol Sci 2019; 404: 72-9. https://doi.org/ 10.1016/j.jns.2019.07.018
24. Sheikh-Bahaei N, Acharya J, Rajamohan A, Kim PE. Advanced imaging techniques in diagnosis of posterior reversible encephalopathy syndrome (PRES). Front Neurol 2020; 11: 165. https://doi.org/10.3389/fneur.2020.00165

25. Gasparini S, Ferlazzo E, Sueri C, Cianci V, Ascoli M, Cavalli SM, et al. Hypertension, seizures, and epilepsy: a review on pathophysiology and management. Neurol Sci 2019; 40: 1775-83. https://doi.org/10.1007/s10072-019-03913-4

26. Chen Z, Zhang G, Lerner A, Wang AH, Gao B, Liu J. Risk factors for poor outcome in posterior reversible encephalopathy syndrome: systematic review and meta-analysis. Quant Imaging Med Surg 2018; 8: 421-32. https://doi.org/ 10.21037/qims.2018.05.07

27. Williams B, Mancia G, Spiering W, Agabiti Rosei E, Azizi M, Burnier M, et al. 2018 ESC/ESH Guidelines for the management of arterial hypertension. Eur Heart J 2018; 39(33): 3021-104. https://doi.org/10.1093/eurheartj/ ehy339

28. Chen S, Hu J, Xu L, Brandon D, Yu J, Zhang J. Posterior reversible encephalopathy syndrome after transplantation: a review. Mol Neurobiol 2016; 53: 6897-909. https://doi.org/10.1007/s12035-015-9560-0

\section{G. V. Urbonaitė, E. Audronytė, J. Valaikienè}

\section{POSTERIOR REVERSIBLE ENCEPHALOPATHY SYNDROME: A CASE REPORT AND REVIEW OF THE LITERATURE}

\section{Summary}

Posterior reversible encephalopathy syndrome (PRES) is a rare condition that is diagnosed based on clinical and radiological findings. Usually this condition manifests with acute neurological symptoms, such as headache, impaired consciousness, seizures and/or vision distubances with fluctuations in arterial blood pressure, and neuroimaging abnormalities of bilateral subcortical vasogenic edema, usually seen in occipital lobes. The pathophysiology of this syndrome is still debated, however, it is thought that PRES develops due to the endothelial dysfunction. PRES should be suspected when acute neurological symptoms develop in patients with renal insufficiency, arterial hypertension or fluctuations in blood pressure, eclampsia, sepsis, and autoimmune diseases who are taking immunosupressive or citotoxic medications. The main treatment consists of the removal of the precipitating factors (correction of arterial hypertension, cessation of immunosupressive treatment or dose reduction). The prognosis is usually good, with a regresion in clinical and radiological symptoms and signs in several days or weeks. Very rarely, PRES can have complications like intracerebral hemmorhage, severe brain edema, and fatal outcome or persisting disability.

In this article, we present a rare clinical case when PRES was diagnosed accidentally during a follow-up head magnetic resonance imaging of meningioma. The patient, who had suffered from chronic headaches for several years, had arterial hypertension with fluctuations in blood pressure. Typical radiological signs of PRES remained visible after 1,3 and 6 months and completely regressed after a year.

Keywords: arterial hypertension, posterior reversible encephalopathy syndrome, PRES, hypertensive encephalopathy, meningioma, headaches.

Gauta:

Priimta spaudai:

20200501 20200514 